\title{
Analysis of Variation Characteristics and Driving Factors of Tonle Sap Lake's Surface Water Temperature from 2001 to 2018
}

\author{
Meie Pan ${ }^{1,2}$, Kun Yang, ${ }^{1,2 *}$ \\ ${ }^{1}$ Faculty of Geography, Yunnan Normal University, Kunming 650500, China \\ ${ }^{2}$ GIS Technology Research Center of Resource and Environment in Western China, Ministry of Education, \\ Yunnan Normal University, Kunming 650500, China
}

Received: 21 June 2020

Accepted: 1 November 2020

\begin{abstract}
Lake surface water temperature (LSWT) has a significant impact on aquatic ecosystem. This study aimed to reveal the variations and driving factors of LSWT in Tonle Sap Lake, the largest freshwater lake in South Asia. For this purpose, the datasets of LSWT-day, atmospheric temperature (AT), lake surface area (LSA), watershed land use and cover change (WLUCC) were extracted based on MODIS products and AT images by remote sensing technology. Then, through GIS geospatial analysis technology and mathematical statistical methods, the spatial-temporal variations of LSWT-day, AT, LSA and WLUCC were analyzed, and the relationships between LSWT-day and AT, LSA, WLUCC were further discussed. Results showed that: 1) from 2001 to 2018, the annual mean LSWT-day and AT showed a significant warming trend. AT was a main driving factor affecting LSWT in Tonle Sap Lake. 2) LSA showed a slightly decreasing tendency and had an obvious negative correlation with LSWT-day, which was an important factor affecting LSWT. 3) WLUCC had undergone drastic changes and its influence on LSWT could not be ignored. In summary, this paper fills the gap of the long-term series of LSWT research in Tonle Sap Lake and enhances the understanding of LSWT changing mechanism for similar lakes.
\end{abstract}

Keywords: LSWT, Tonle Sap Lake, air temperature, lake surface area, LUCC, MODIS

\section{Introduction}

Lakes have important ecological and economic values. Lake water temperature (LWT) is a critical physical property of a lake, which has great significance

*e-mail:kmdcynu@163.com for other researches, such as lake water quality, energy cycle, aquatic ecosystem [1]. Lake surface water temperature (LSWT) refers to the temperature of a very thin layer (from $0 \mathrm{~m}$ to $1 \mathrm{~m}$ ) on the lake surface [2]. It can directly reflect the process of material and energy exchange between the lake and the atmosphere, as well as between the lake and the surrounding surface, and is an important indicator of aquatic ecosystem [3, 4]. 
Over the past few decades, the LSWT of most of the world's lakes has been warming rapidly, which causes dynamic and complicated effects on the physical, biological and chemical processes of aquatic ecosystem [5-8]. Accordingly, it is significant to study the variation characteristics and driving factors of LSWT for protecting the water environment.

Nowadays, remote sensing images are used to extract the long time series of LSWT and monitor its variation characteristics. Schaeffer et al. [9] used Landsat images to extract the LSWT of 35 lakes and reservoirs in America. Results showed that, the average absolute error of pixels larger than $180 \mathrm{~m}$ from the lake edge was $1.34^{\circ} \mathrm{C}$. Based on AVHRR images, Schneider et al. [10] extracted the LSWT-night of 167 large inland lakes from 1985 to 2009. The deviation was $0.15^{\circ} \mathrm{C}$. Recently, more and more scholars use Moderate Resolution Imaging Spectroradiometer (MODIS) Land Surface Temperature (LST) data (MOD11A2) to extract LSWT. The validations of MOD11A2 image have been conducted and showed good performances for Lake Tahoe in North America [11], lakes Vänern in Sweden [12], lakes in the Tibetan Plateau [13-15], lakes in Yunnan-Guizhou Plateau [16]. MODIS LST products are more suitable for large-scale, high frequency and long-term LSWT research.

Previous studies show that there are many driving factors for LSWT changes, such as climate change (atmospheric temperature, AT), human activities (land use type around lakes), watershed geomorphology, lake morphology, hydrological characteristics, water quality and so on. Among them, the impacts of climate change on LSWT have been widely studied. Livingstone et al. [17] found that the AT was significantly correlated with LSWT of eight lakes in northern Austria. Xiao et al. [18] found that AT warming was the main reason for LSWT changes in lakes of the Qinghai Tibet Plateau. At the same time, the topography of the lake basin and the distribution of drainage determined the temporalspatial patterns of LSWT. Sharma et al. [19] indicated maximum near-surface temperatures for Canadian lakes appeared to be dominated by large-scale climatic and geographic patterns, rather than lake-specific variables, such as lake morphology and water chemistry. Yang et al. [20] indicated LSWT have also risen in areas where water quality has deteriorated. Woolway et al. [21] indicated that the decreasing lake area can increase the near-surface diel temperature range. Yang et al. [22] found that human activities had a significant impact on LSWT of urban lake in 11 lakes of Yunnan-Guizhou plateau. It can be seen the driving factors of LSWT are discrepant in different lakes.

Tonle Sap Lake is the largest freshwater lake in South Asia, and a world-famous producing area of freshwater fish. Its biodiversity importance is reflected in its international protection status [23]. Tonle Sap lake is also famous for the unique flood-pulse. There is a huge difference in water volume between the dry season (about $2500 \mathrm{~km}^{2}$ ) and rainy season (about
$16,000 \mathrm{~km}^{2}$ ). During the rainy season, water flows from the surging Mekong River to Tonle Sap Lake through the Tonle Sap River, while during the dry season, the flow is reversed [24]. Due to this natural phenomenon, Tonle Sap Lake is of great significance to flood control, economic development, and the ecological value of Cambodia. At present, the researches of Tonle Sap Lake mainly focus on biodiversity [25-27], water quality [28-30], hydrological characteristics [31-33], social and economic conditions [34, 35].

To sum up, the variation characteristics and driving factors of Tonle Sap Lake's LSWT are rarely studied. There are also few reports on the influence of unique flood-pulse on LSWT. It is of great practical significance to explore the change mechanism of Tonle Sap Lake's LSWT for the protection of lake ecosystem. Therefore, this study aimed to: 1) analyze the temporal and spatial variation characteristics of Tonle Sap Lake's LSWT from January 2001 to December 2018 in detail, 2) quantitatively reveal the relationships between LSWT and AT, lake surface area (LSA), watershed land use and cover change (WLUCC). This paper fills the gap of the long-term series of LSWT research in Tonle Sap Lake, and provides methodological reference for the analysis on the change mechanism of LSWT in similar lakes.

\section{Material and Methods}

\section{Study Area}

Tonle Sap Lake is located at $11^{\circ} 53^{\prime}-14^{\circ} 08^{\prime} \mathrm{N}$ and $102^{\circ} 30^{\prime}-105^{\circ} 29^{\prime} \mathrm{E}$, in northwest of Cambodia. It comprises a permanent lake area and floodplains (Fig. 1). The climate of the study area is characterized by a long southwest monsoon rainy season, from May to October, and a dry northeast monsoon season from November to April. The annual mean precipitation is between 1300 and $1500 \mathrm{~mm}$. Tonle Sap Lake's flood pulse provides high fishery yield and good irrigation conditions for thousands of farmland in the surrounding plain area [36]. In 2014, the population of the lake area was 7.443 million and the GDP was about 7.44 billion dollars, accounting for about $50 \%$ and $44 \%$ of the country, respectively. The lake is critically important in economic development for Cambodia and the lower Mekong River Basin. In addition, Tonle Sap Lake is important in protecting biodiversity and water ecological functions, and is very sensitive to global changes. Because of its importance, Tonle Sap Lake has always been a research hotspot for scholars.

\section{Data Sources}

In this study, the research data mainly includes LSWT, AT, LSA and WLUCC from January 2001 to December 2018. Other auxiliary data includes lake (permanent lake) boundary (LB), floodplain boundary 


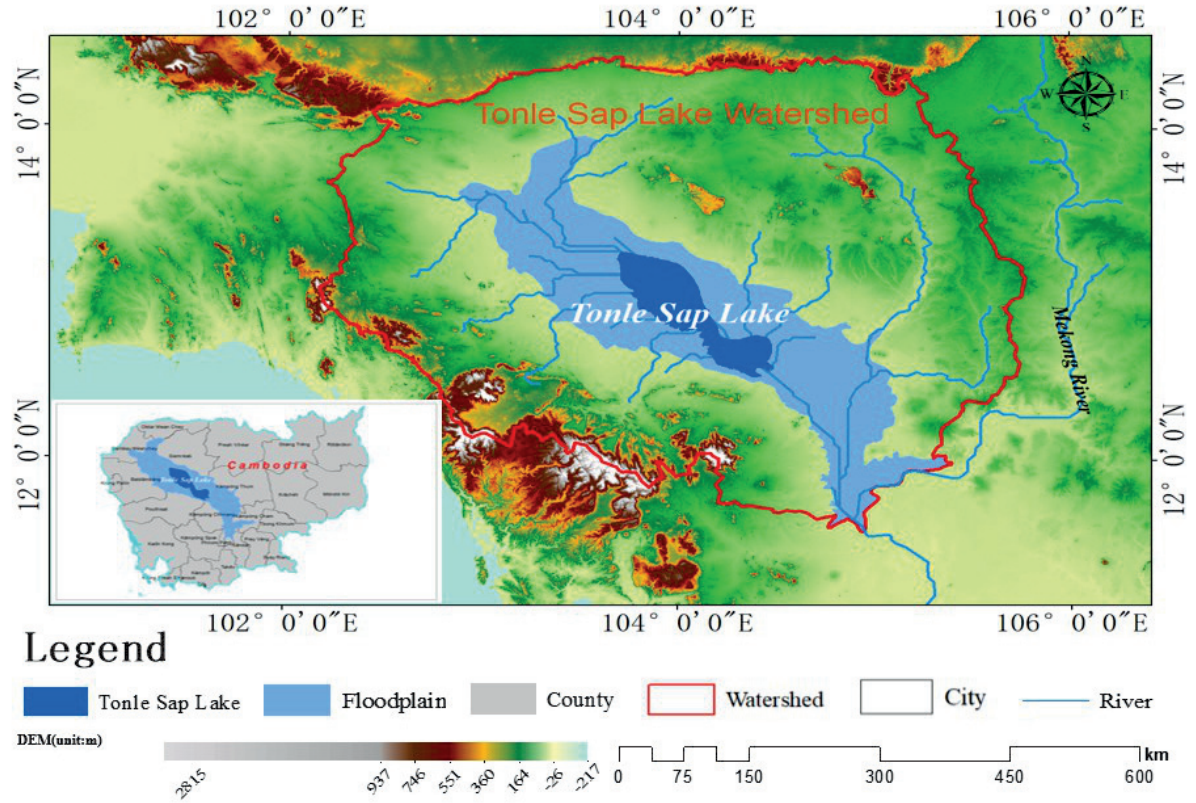

Fig. 1. Location of Tonle Sap Lake. The boundaries of Tonle Sap Lake (permanent lake area) and floodplain are obtained by the visual interpretation of Landsat8 OLI images. The watershed and river derived from SRTM 90m DEM using ArcGIS hydrologic analysis tool. The boundaries of Country and Province derived from GADM DATA.

(FB), river, watershed boundary (WB), country boundary $(\mathrm{CB})$ and province boundary $(\mathrm{PB})$. As shown in Table 1, over 1900 images were obtained from various websites.

Among them, LSWT is extracted by MOD11A2 (Path28, Row07) Level-3 MODIS LST and Emissivity (LST/E) 8-day products. There are 46 images every year. AT is obtained from NOAA's 2015 Global Historical Climatology Network and the Climate Anomaly Monitoring System (GHCM_CAMS) monthly mean temperature data set at $2 \mathrm{~m}$ above the ground. There are 12 images every year. LSA is extracted by MOD09A1 (Path28, Row07) images, which provide surface spectral reflectance estimation of Terra MODIS band 1-7 at $500 \mathrm{~m}$ resolution. There are 46 images for Tonle Sap Lake every year. WLUCC is extracted by MCD12Q1 (h27v07, h28v07) products, which provide global land cover types at yearly intervals by using supervised classification based on MODIS Terra and
Aqua reflectance data. There are 2 images for Tonle Sap Lake watershed every year. LB and FB are extracted by Landsat-8 OLI images (Path126, Row51 and Path127, Row51). There are 4 images for this study. WB and river are derived from SRTM 90m DEM using ArcGIS hydrologic analysis tool. The boundaries of country and province are derived from GADM DATA (version 3.6, released on 6 May 2018).

\section{Methods}

The strategy for analyzing the various characteristics and driving factors of Tonle Sap Lake's LSWT from 2001 to 2018 was shown in Fig. 2.

\section{$L B$ and FB Extraction}

Due to the extreme seasonal changes in the water area of Tonle Sap Lake, through the comparative analysis

Table 1. Data sources of Tonle Sap Lake.

\begin{tabular}{|c|c|c|c|c|c|}
\hline Dataset & \multicolumn{2}{|c|}{ Resolution } & Amount & Source & URL \\
\hline MOD11A2 & $1000 \mathrm{~m}$ & 8 -day & $46 * 18$ & NASA & $\mathrm{https://adsweb.modaps.eosdis.nasa.gov/}$ \\
\hline GHCM_CAMS & $0.5^{\circ}$ & monthly & $12 * 18$ & NOAA & $\mathrm{https://www.esrl.noaa.gov/}$ \\
\hline MOD09A1 & $500 \mathrm{~m}$ & 8 -day & $46 * 18$ & GEE & $\mathrm{https://code.earthengine.google.com}$ \\
\hline MCD12Q1 & $500 \mathrm{~m}$ & yearly & $2 * 18$ & NASA & $\mathrm{https://ladsweb.modaps.eosdis.nasa.gov/}$ \\
\hline Landsat-8 OLI & $30 \mathrm{~m}$ & 16 -day & 4 & USGS & $\mathrm{https://earthexplorer.usgs.gov/}$ \\
\hline SRTM/DEM & $90 \mathrm{~m}$ & & 1 & GDC & $\mathrm{http} / / / \mathrm{www} \cdot g s c l o u d . c n /$ \\
\hline CB, PB & & & & GADM & $\mathrm{https://gadm.org/}$ \\
\hline
\end{tabular}




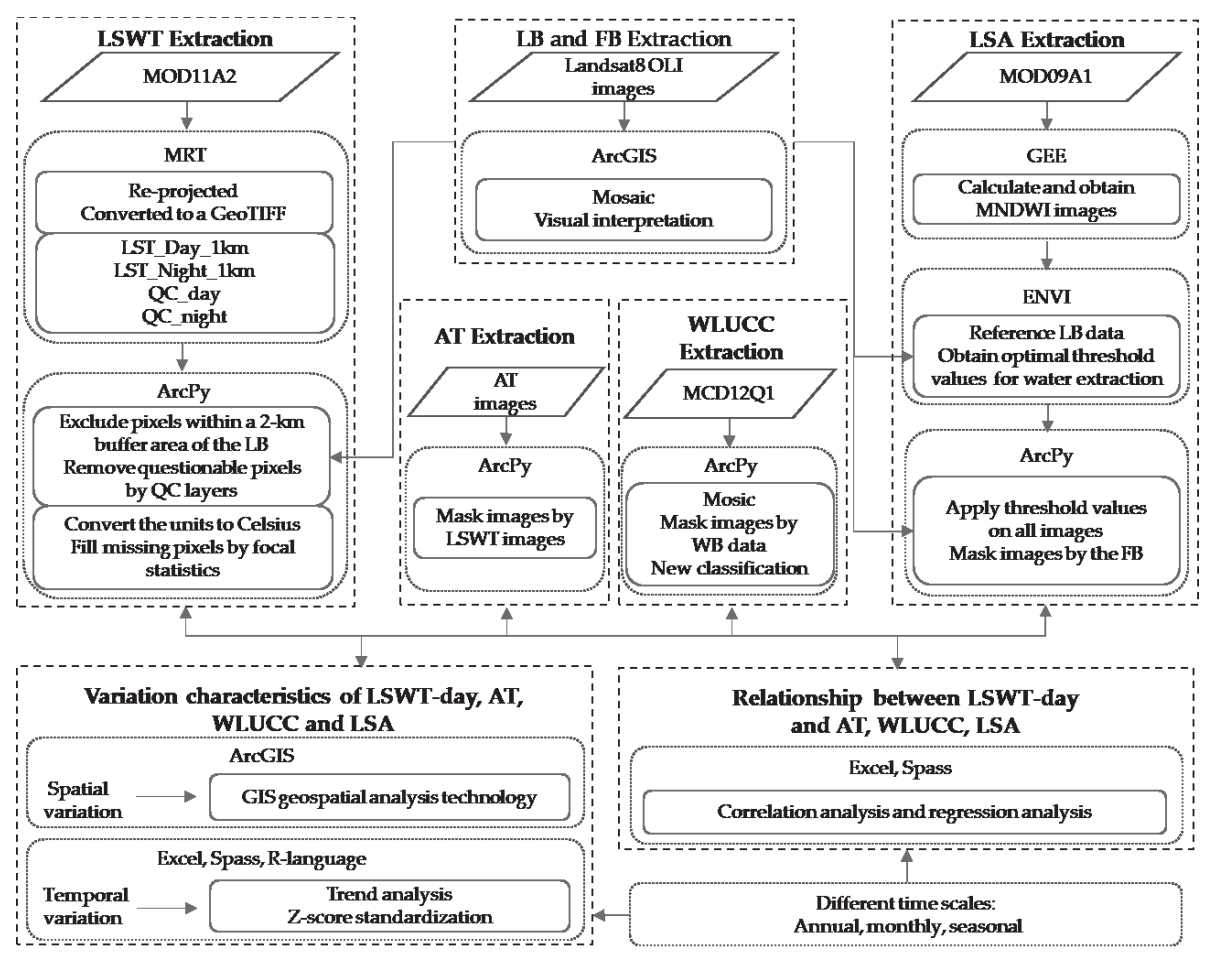

Fig. 2. Strategy for analyzing the variation characteristics and driving factors of Tonle Sap Lake's LSWT from 2001 to 2018.

of multiple Landsat satellite images, LB was extracted based on Landsat8 OLI images in the dry season on March 22 (Path126, Row51) and March 29 (Path127, Row51), 2016. FB was extracted based on Landsat8 OLI images in the flood season on November 10 (Path126, Row51) and November 17 (Path127, Row51), 2019. With the support of ArcGIS 10.5 software, LB and FB were accurately obtained by mosaic and visual interpretation.

\section{LSWT Extraction}

First, MOD11A2 images were re-projected and converted to a GeoTIFF format by MODIS Reprojection Tool (MRT, https://lpdaac.usgs.gov/tools/ modis_reprojection_tool). Four layers including LST Day_1km, LST_Night_1km, QC day and QC night were exported from the MOD11A2 products. Second, considering annual water level inconsistency and subpixel effect along the shoreline, this study excluded pixels of four layers within a $2-\mathrm{km}$ buffer area of the LB.

Due to the influence of clouds, it is necessary to filter unreliable LST pixels. Based on collection-5 MODIS LST Products Users' Guide, this study followed four steps to remove questionable pixels in the LST images over the lake. First, those pixels outside the LST valid range (7500-65535) were replaced with null values. Second, with the reference of QC layers, all pixels with good quality in the first labels, or the pixels with LST error less than or equal to $1 \mathrm{~K}$ and the pixels with good quality in the second labels, or the pixels with LST error less than or equal to $2 \mathrm{k}$ and emissivity error less than 0.02 in the third labels were retained, and pixels with other QC labels were removed. Third, we masked the LST file with QC result file to get a valid temperature data, and then converted units to Celsius $\left({ }^{\circ} \mathrm{C}\right)$. Finally, we filled the missing value of pixels by Focal Statistics. The specific method of focal statistics is: calculate the mean value of $5 \times 5$ pixels around the missing pixels, and then fill it to the new value. Because there were too many missing pixels from night-time LST images, this study only analyzed the change of daytime temperature (LSWT-day). The above steps were completed with the support of ArcPy software.

\section{LSA Extraction}

According to the previous papers, MNDWI index using equation (1) has a good performance for water extraction [37]. The Google Earth Engine (GEE) platform integrates massive satellite images, and provides basic computing functions and APIs. First, MNDWI was calculated and obtained on GEE platform based on MOD09A1 images. Second, Landsat8 OLI images in the dry season on March 22 (Path126, Row51) and March 29 (Path127, Row51), 2016 and in the flood season on November 10 (Path126, Row51) and November 17 (Path127, Row51), 2019 were obtained. Mosaic and visual interpretation were performed, and the results were used as a benchmark. Third, with the support of ENVI software, through multiple comparison and adjustments, the optimal threshold of MNDWI (-0.1) was obtained to water extraction. Then, the threshold was applied to all images with the support of ArcPy software. Finally, the Tonle Sap Lake water body images were extracted through masking all images by 
FB data. LSA was calculated based on ArcGIS 10.5 software.

The MNDWI is defined as follows:

$$
\text { MNDWI }=\frac{\rho_{\text {Green }}-\rho_{\mathrm{SWIR}}}{\rho_{\mathrm{Green}}+\rho_{\mathrm{SWIR}}}
$$

In this formula, $\rho_{\text {Green }}$ and $\rho_{\text {SWIR }}$ represent the Green and SWIR bands reflectance, respectively.

\section{WLUCC Extraction}

MCD12Q1 V6 products map global land cover for six different classification schemes. This study used International Geosphere-Biosphere Programme (IGBP) classification scheme to analyze the land use status of Tonle Sap lake watershed. The IGBP classification scheme includes 17 land use subclasses. Based on the characteristics of land cover in study area, 17 subclasses were merged into 9 land-use types, as shown in Table 2. Finally, MCD12Q1 images were mosaiced (h27v07, h28v07) and masked by WB data. WLUCC images were obtained from 2001 to 2018 .

Table 2. New classification system of WLUCC.

\begin{tabular}{|c|c|c|c|}
\hline \multicolumn{2}{|c|}{ New classification scheme } & \multicolumn{2}{|c|}{ IGBP classification scheme } \\
\hline Code & Name & Code & Name \\
\hline \multirow{6}{*}{1} & \multirow{6}{*}{ Forest } & 1 & $\begin{array}{l}\text { Evergreen Needleleaf } \\
\text { Forests }\end{array}$ \\
\hline & & 2 & $\begin{array}{c}\text { Evergreen Broadleaf } \\
\text { Forests }\end{array}$ \\
\hline & & 3 & $\begin{array}{c}\text { Deciduous Needleleaf } \\
\text { Forests }\end{array}$ \\
\hline & & 4 & $\begin{array}{c}\text { Deciduous Broadleaf } \\
\text { Forests }\end{array}$ \\
\hline & & 5 & Mixed Forests \\
\hline & & 8 & Woody Savannas \\
\hline \multirow{2}{*}{2} & \multirow{2}{*}{ Shrubland } & 6 & Closed Shrublands \\
\hline & & 7 & Open Shrublands \\
\hline \multirow{2}{*}{3} & \multirow{2}{*}{ Grassland } & 9 & Savannas \\
\hline & & 10 & Grasslands \\
\hline 4 & Wetland & 11 & Permanent Wetlands \\
\hline \multirow[b]{2}{*}{5} & \multirow[b]{2}{*}{ Cropland } & 12 & Croplands \\
\hline & & 14 & $\begin{array}{c}\text { Cropland/Natural Veg- } \\
\text { etation Mosaics }\end{array}$ \\
\hline 6 & Impervious surface & 13 & $\begin{array}{l}\text { Urban and Built-up } \\
\text { Lands }\end{array}$ \\
\hline 7 & Snow/Ice & 15 & Permanent Snow and Ice \\
\hline 8 & Bare land & 16 & Barren \\
\hline 9 & Water & 17 & Water Bodies \\
\hline
\end{tabular}

\section{Trend Analysis}

Linear regression is a statistical analysis method to determine the interdependent quantitative relationship between two or more variables. In this study, the change rates of LSWT, AT, LSA and WLUCC were estimated using Equation (2).

$$
y=a+b x+e
$$

In this formula, $\mathrm{y}$ is LSWT or AT or LSA or WLUCC. $x$ is the time series. $e, a$ and $b$ represent the residuals, intercept, and change rate, respectively. $a$ and $b$ are determined by least squares fitting.

\section{Z-score Standardization}

Due to the different dimensions and orders of magnitude of LSWT, AT, LSA and WLUCC, in the comprehensive analysis, it is necessary to treat them as dimensionless standardized data. The Z-score is a standardized form for converting common variables to standard scores. It is defined as:

$$
x_{i j}^{\prime}=\frac{x_{i j}-\bar{x}_{j}}{\sigma_{j}}
$$

$\bar{x}_{j}$ and $\sigma_{j}$ are the sample mean and standard deviation of the jth attribute, respectively. $x_{i j}$ is the value of the jth variable in year i. $x_{i j}^{\prime}$ represents the normalized value.

\section{Correlation Analysis}

In this paper, the correlations between LSWT and AT, LSA, WLUCC were analyzed by Pearson correlation coefficient. The expression is Equation (4).

$$
r=\frac{\sum_{i=1}^{n}\left(x_{i}-\bar{x}\right)\left(y_{i}-\bar{y}\right)}{\sqrt{\sum_{i=1}^{n}\left(x_{i}-\bar{x}\right)^{2}\left(y_{i}-\bar{y}\right)^{2}}}
$$

In this formula, $r$ represents the Pearson correlation coefficient. $x_{i}$ represents LSWT. $y_{i}$ represents AT or LSA or WLUCC. $\bar{x}$ and $\bar{y}$ represent the average value.

\section{Regression Analysis}

In order to quantitatively analyze the relationships between the LSWT and AT, LSA, WLUCC, the polynomial regression model was used. The suitability of the model was assessed by goodness of fit $\left(\mathrm{R}^{2}\right)$. The expression is defined as:

$$
y=a x^{2}+b x+c
$$

...where $y$ is LSWT, $x$ is AT or LSA or WLUCC. $a, b$ and $c$ are the model coefficients determined by least squares fitting. 


\section{Results and Discussion}

\section{Variation Characteristics of Tonle Sap Lake's LSWT-day}

\section{Temporal Variation Characteristics}

Through the trend analysis, the annual maximum and annual average LSWT-day of Tonle Sap Lake showed upward trends (about $0.3^{\circ} \mathrm{C}$ per decade), and the annual minimum LSWT-day had a downward trend (about $0.2^{\circ} \mathrm{C}$ per decade) from 2001 to 2018 (Fig. 3a). Among them, the lowest annual average LSWT-day occurred in $2001\left(\mathrm{Tmin}=26.07^{\circ} \mathrm{C}\right)$, and the highest values occurred in $2015\left(\operatorname{Tmax}=27.46^{\circ} \mathrm{C}\right)$. The annual minimum LSWT-day values varied from $20.86^{\circ} \mathrm{C}$ to $23.74^{\circ} \mathrm{C}$. The annual maximum LSWT-day values varied from $29.50^{\circ} \mathrm{C}$ to $31.67^{\circ} \mathrm{C}$. In general, the changes of Tonle Sap Lake's LSWT-day were characterized by large intra-annual variation and small inter-annual variation.

Fig. 3b) revealed the season-scale variations. The average LSWT-day of Tonle Sap Lake in spring (from March to May) showed a significant upward trend, with a rate of $0.06^{\circ} \mathrm{C} /$ year. It was significantly higher than that in other seasons. In contrast, LSWT-day in summer and autumn had a downward trend. The rate of decline was $0.02^{\circ} \mathrm{C} /$ year and $0.03^{\circ} \mathrm{C} /$ year, respectively. The warming rate in winter was $0.015^{\circ} \mathrm{C} /$ year. Overall, the Tonle Sap Lake's LSWT-day fluctuated greatly in spring and summer, and was relatively stable in autumn and winter.

The month-scale analysis of LSWT-day was shown in Fig. 3c). The period from January to April (dry season) represented the increasing stage. In particular, the highest warming trend occurred in
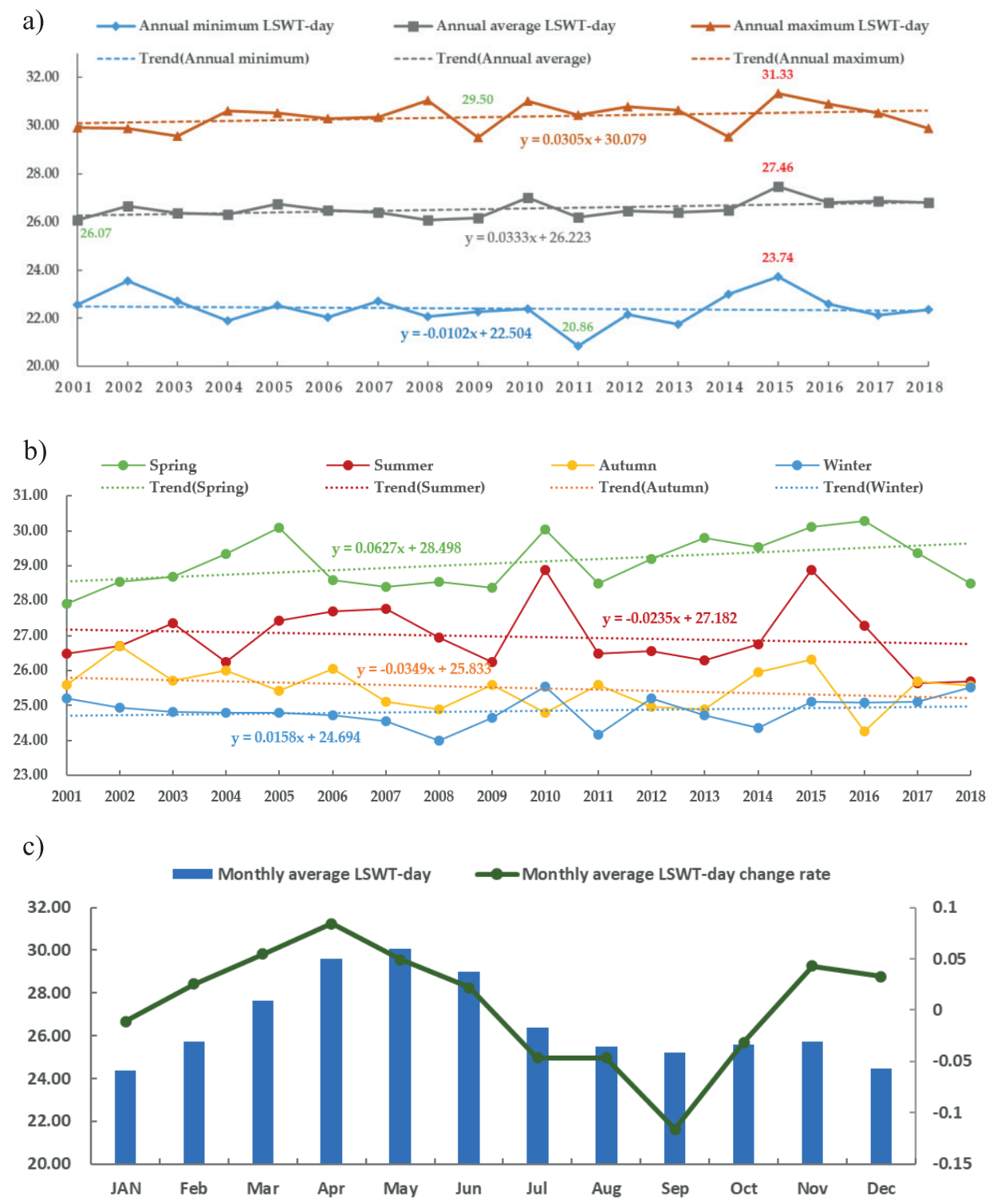

Fig. 3. Temporal variation of Tonle Sap Lake's LSWT-day from 2001 to 2018. a) the annual change; b) the seasonal change; c) the monthly change. 
April, with a warming rate of $0.08^{\circ} \mathrm{C} /$ year. The warmest month was May during which the monthly average LSWT-day reached $30.04^{\circ} \mathrm{C}$. In May, ten annual maximum values of daily LSWT-day occurred during these 18 years. During the period from May to September (rainy season), the monthly average LSWT-day indicated the opposite change trends. The maximum decline rate was $0.12^{\circ} \mathrm{C} /$ year, it occurred in September. It can be seen the LSWT-day in the rainy season was significantly lower than that in the dry season.

\section{Spatial Variation Characteristics}

From 2001 to 2018, the spatial distribution characteristics of annual average LSWT-day in Tonle Sap Lake were similar (Fig. 4a). The south, east and the northeast parts of the lake mostly had higher annual average LSWT-day. Generally, the highest LSWT-day for different years were found in the southern part of the lake. During the study period, LSWT-day in 2015 was significantly higher than that in other years, while LSWT in 2001 had the lowest annual average value. Tonle Sap Lake's LSWT showed a fluctuating rise. a)

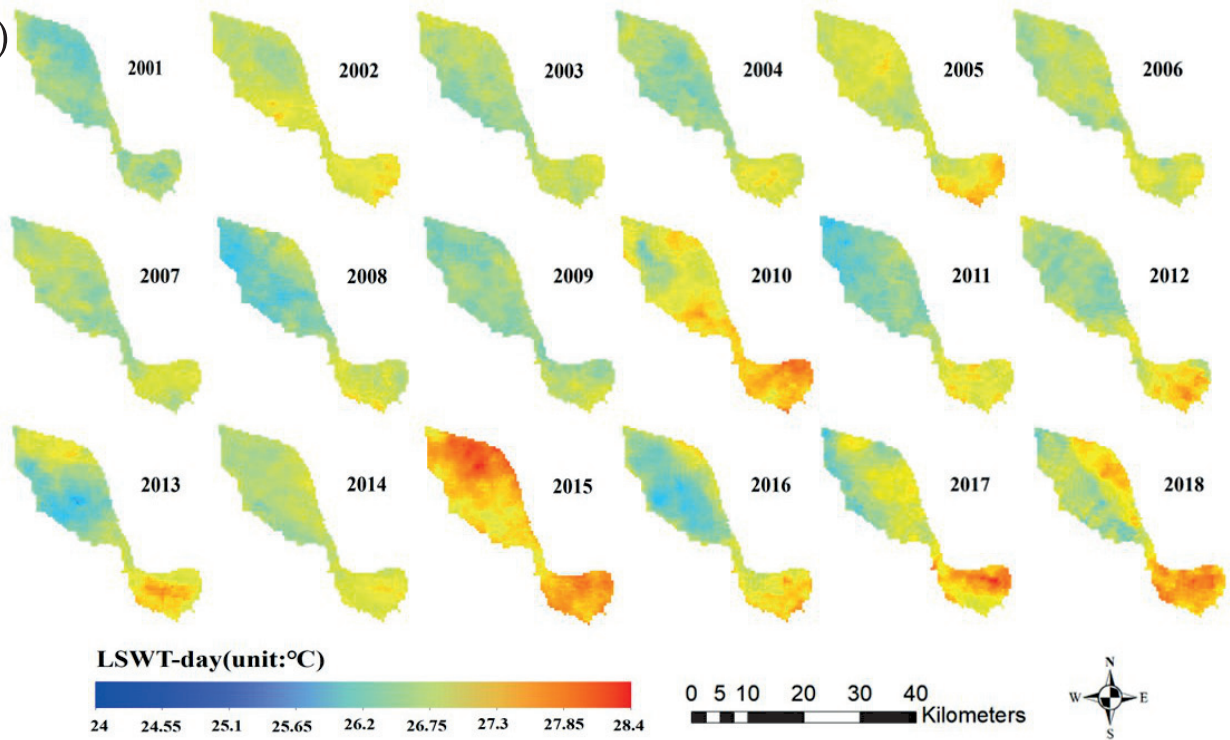

b)

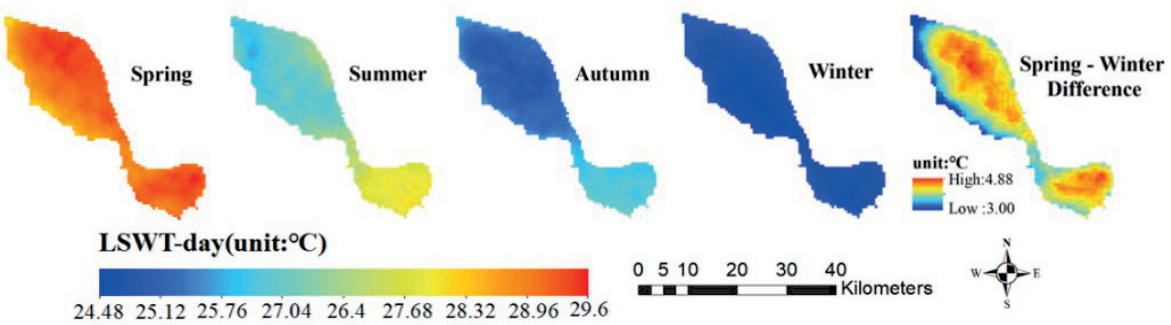

c)

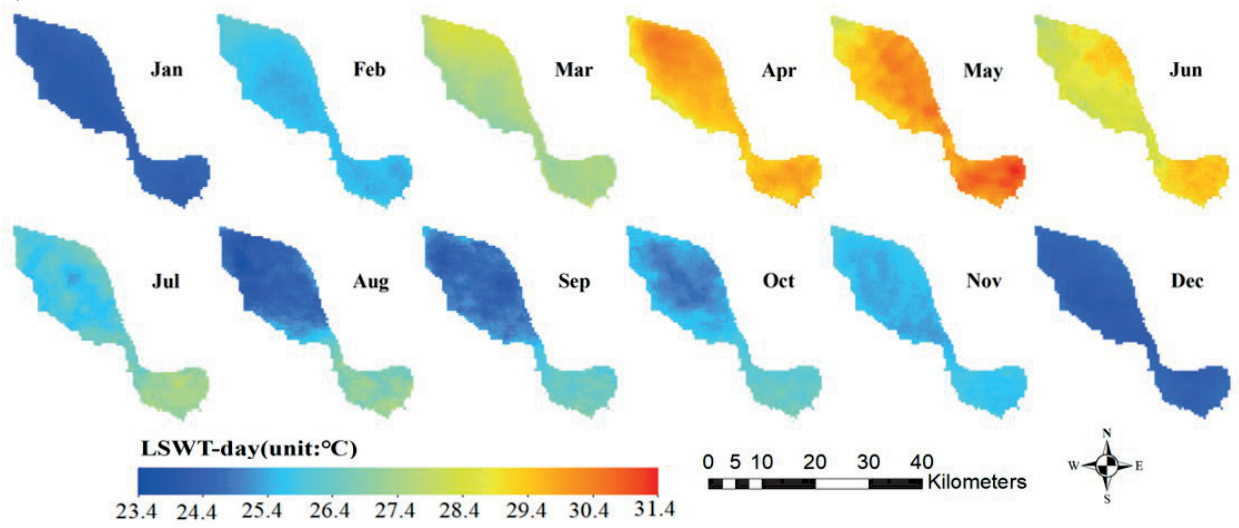

Fig. 4. Spatial patterns of LSWT-day from 2001 to 2018. a) the annual average LSWT-day spatial distribution; b) the seasonal average LSWT-day spatial distribution; c) the monthly average LSWT-day spatial distribution. 
The spatial patterns of the seasonal average LSWT-day were spatially coincident with the annual average LSWT-day (Fig. 4b). The highest LSWT-day for different season was still found in the south and northeast of the lake. Spring was the season with the highest LSWT-day, while winter was the season with the lowest values. The temperature difference between spring and winter ranged from 3 to $4.88^{\circ} \mathrm{C}$. The highest temperature difference occurred in the central parts of the lake.

The spatial patterns of the monthly average LSWT-day from 2001 to 2018 were revealed in Fig. 4c). The monthly average LSWT-day became gradually higher from the west shores to the east shores of the lake, and showed obvious change characteristics. From January to May, the LSWT-day warmed regularly, and the LSWT-day dropped gradually from June to December. The monthly mean LSWT-day of the whole lake reached its peak in May.

In summary, this study obtained the long-term series variation characteristics of Tonle Sap Lake's LSWT. From 2001 to 2018, the annual average LSWT-day of Tonle Sap Lake showed an obvious warming trend and spatial heterogeneity, with a warming rate of $0.3^{\circ} \mathrm{C}$ per decade. The warming trend is consistent with most lakes around the world (global mean $=0.34^{\circ} \mathrm{C}$ per decade) $[3]$.

\section{Driving Factors Analysis of Tonle Sap Lake's LSWT-day Warming}

\section{Variation Analysis of AT, LSA and WLUCC}

Under the pressure of global warming, the annual mean, maximum and minimum AT over Tonle Sap Lake increased significantly from 2001 to 2018, with the average warming rates were $0.37^{\circ} \mathrm{C}$ per decade (Fig. 5). This warming trend is consistent with the AT $\left(0.036 \pm 0.027^{\circ} \mathrm{C} /\right.$ year $)$ of 52 lakes in the Tibetan Plateau [13], and the near-surface AT $\left(0.39^{\circ} \mathrm{C}\right.$ per decade $)$ of 11 lakes in Yunnan Guizhou plateau [22]. The annual average AT varied from $27.30^{\circ} \mathrm{C}$ to $28.56^{\circ} \mathrm{C}$. The lowest AT occurred in $2008\left(27.17^{\circ} \mathrm{C}\right)$, and the highest AT occurred in $2016\left(28.74^{\circ} \mathrm{C}\right)$. Based on the monthly change analysis, the month with the highest temperature was April and the lowest temperature was January. AT was on the rise from January to April, and dropped slowly since May. According to the seasonal analysis,

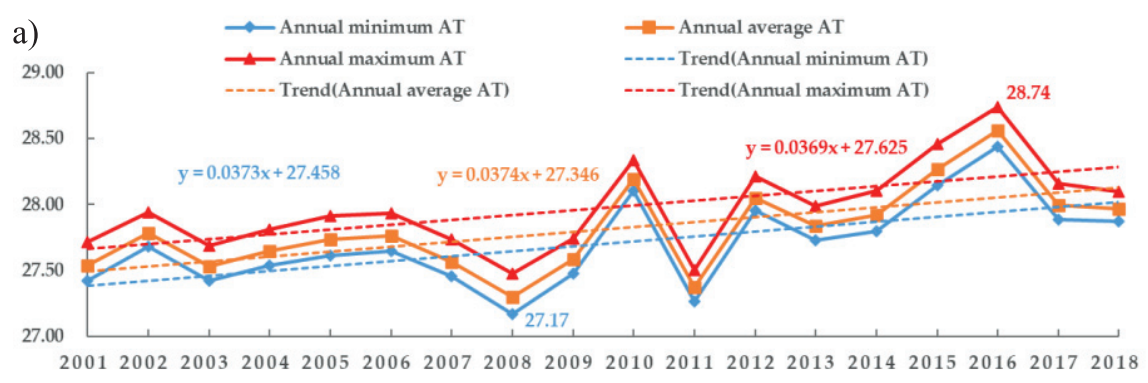

b)
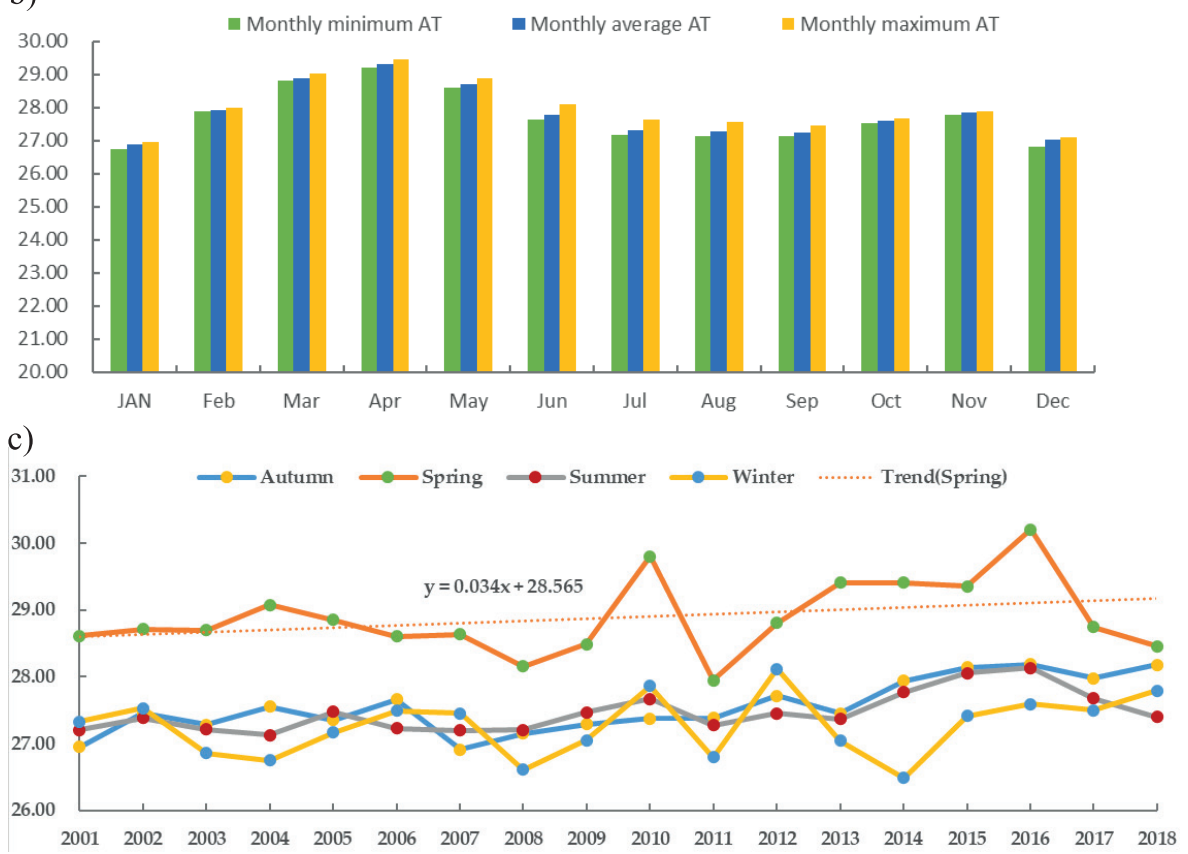

Fig. 5. Variation analysis of AT over Tonle Sap Lake from 2001 to 2018. a) the annual change; b) the monthly change; c) the seasonal change. 


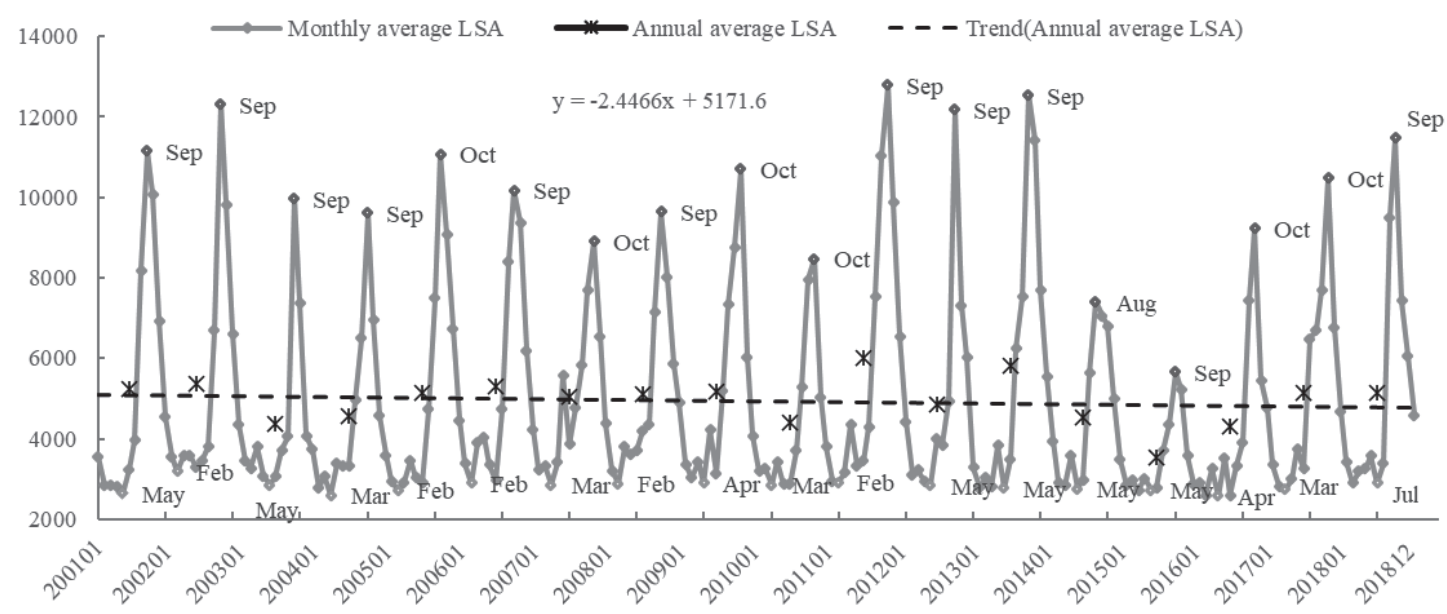

Fig. 6. Variation analysis of LSA from 2001 to 2018. The red dots represent the months with the maximum monthly average LSA and the orange dots represent the months with the minimum monthly average LSA each year. The black dots represent the annual average LSA.

spring was the season with the highest AT, and with a warming rate of $0.03^{\circ} \mathrm{C} /$ year. The temperature difference of other seasons was small. This phenomenon is highly consistent with variation characteristics of LSWT-day.

The LSA of Tonle Sap Lake (2001-2018) displayed a slightly decreasing tendency (Fig. 6). The interannual variations of LSA from 2001 to 2009 remained relatively stable. On the contrary, the annual average LSA fluctuations were more obvious from 2009 to 2018. The minimum and maximum annual average LSA occurred in $2015\left(3540.67 \mathrm{~km}^{2}\right)$ and 2011 $\left(6023.48 \mathrm{~km}^{2}\right)$, respectively. Intra-annual variations of LSA were significant and with common characteristics. During the dry season (November to April next year), the LSA significantly decreased. Correspondently, the LSA significantly increased in the rainy season (from May to October). The maximum monthly average LSA mainly occurred in September, and the minimum value mainly occurred in May. During the study period, the maximum monthly mean LSA appeared in October 2011, with a value of $12794.75 \mathrm{~km}^{2}$, and the minimum value $\left(2573.5 \mathrm{~km}^{2}\right)$ appeared in April 2016. The huge difference in LSA between the dry and rainy seasons form the unique hydrological characteristics of Tonle Sap Lake. In the past 20 years, the development of the Lancang river hydropower stations has influenced significantly the flow of the Mekong River. Major hydropower stations along the main stream of Lancang river include Manwan (1996), Dachaoshan (2001), Jinghong (2008), Xiaowan (2009), Gongguoqiao (2011), and Nuozhadu (2012) hydropower stations. The potential impacts of hydropower station construction on the area of Tonle Sap lake have been widely concerned [38]. In this study, the LSA was about $6150 \mathrm{~km}^{2}$ on average

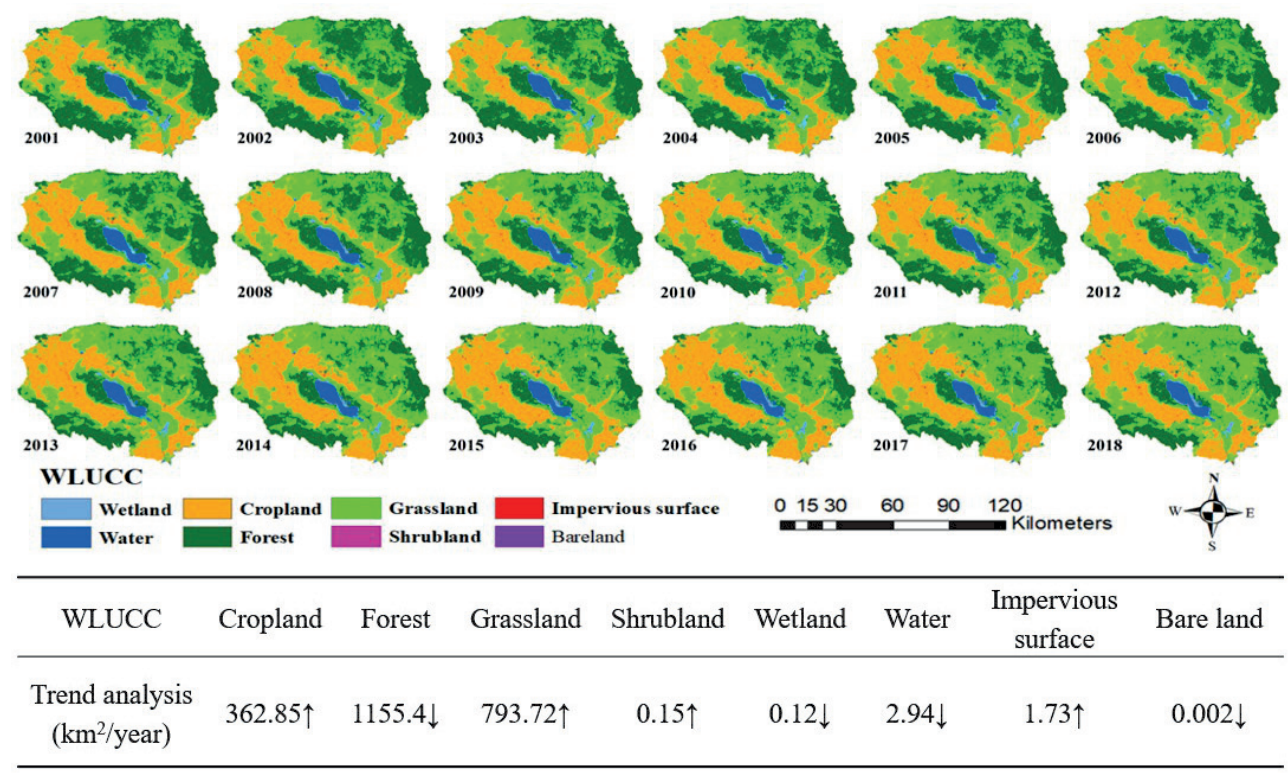

Fig. 7. Variation analysis of WLUCC from 2001 to 2018. 


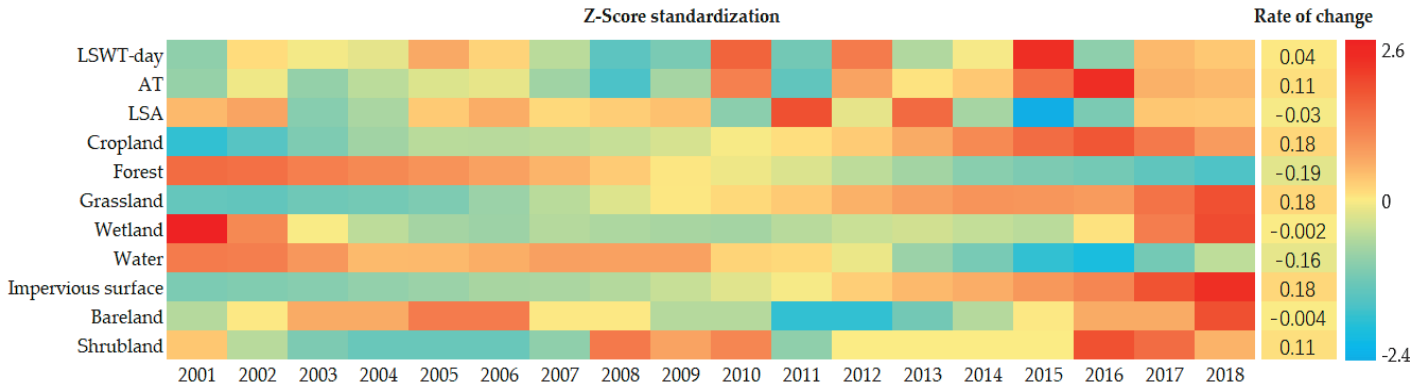

Fig. 8. Variation analysis of LSWT-day, AT, LSA and WLUCC based on Z-Score standardization values.

during the flood season and $3845 \mathrm{~km}^{2}$ on average during the dry season from 2001 to 2007. From 2008 to 2018, the average LSA during the flood season and dry season was $5956 \mathrm{~km}^{2}$ and $3868 \mathrm{~km}^{2}$, respectively. It can be seen the development of hydropower stations can store flood water and relieve drought. This conclusion is consistent with Ji's research [39].

As shown in Fig. 7, the main land cover types in Tonle Sap Lake watershed were forest, grassland, cropland, water, wetland, and impervious surface. From 2001 to 2018, forest gradually was transferred to grassland, and a part of the grassland further was transferred to cropland. The forest area had decreased significantly, with an annual decrease of $-1,155.4 \mathrm{~km}^{2}$. Grassland had the fastest growing rate, with a change rate of $793.72 \mathrm{~km}^{2} /$ year. The second was cropland, with a growth rate of $362.85 \mathrm{~km}^{2} /$ year. In addition, the impervious surface also showed an increasing trend $\left(1.7343 \mathrm{~km}^{2} /\right.$ year). It can be seen WLUCC was greatly affected by human activities. The significant increase in cropland indicated that agriculture was still the first pillar industry of the region's national economy. Due to its superior natural conditions, this region is an important agricultural and rice producing area in Cambodia [35]. In contrast, impervious surface covered a small proportion of watershed area and the low growth rate showed the urbanization process of Tonle Sap Lake watershed was slow.

To comprehensively compare the variation characteristics of LSWT-day, AT, LSA and WLUCC, the experiment of $\mathrm{Z}$-score standardization analysis was added. Through Z-score algorithm, LSWT-day, AT, LSA and WLUCC with multi dimensions and multi orders of magnitude were standardized. The standardized data shows which direction each attribute value is far away from the attribute mean and the distance from the attribute mean. As shown in Fig. 8, Z-score standardization values visually showed the change of variables from year to year. Using trend analysis method, the change rates of the standardized data from 2001 to 2018 were calculated. Under the influence of human activities, WLUCC changed dramatically (Cropland, grassland and impervious surface showed a fast growth; Forests and water had been drastically reduced). In addition, AT and LSWTday were also on the rise.

\section{Relationship Analysis between LSWT-day and AT, LSA, WLUCC}

Pearson correlation coefficients (r) were used to analyze the correlations between LSWT-day and AT, LSA, WLUCC for different time scales (Fig. 9). For monthly time scale, the LSWT-day was obviously correlated with AT $(r=0.69)$ and LSA $(r=-0.45)$. According to the seasonal mean correlation analysis, in spring, the LSWT-day was influenced by both AT $(r=0.82)$ and LSA $(r=-0.52)$. In summer, LSA $(\mathrm{r}=-0.61)$ was the main driving factor for the variations of LSWT-day. By contrast, the effects of AT and LSA on LSWT-day were weak in autumn. In winter, LSWTday was mainly affected by AT $(r=0.80)$. In addition, the effects of AT and LSA on LSWT-day during the dry and rainy seasons were discussed. During the rainy season, LSA was an important factor affecting LSWTday $(r=-0.58)$. During the dry season, both AT and LSA affected LSWT-day, with a correlation coefficient of 0.86 and -0.58 , respectively. For annual time scale, the results showed that LSWT-day significantly correlated with AT $(r=0.78)$ and LSA $(r=-0.71)$, and moderately correlated with the area of cropland $(\mathrm{r}=0.52)$, impervious surface $(\mathrm{r}=0.49)$, water $(\mathrm{r}=-0.58)$ and forest $(\mathrm{r}=-0.44)$, and weakly correlated with the area of grassland $(\mathrm{r}=0.39)$ and bare land $(\mathrm{r}=0.33)$. Overall, the AT and the area of impervious surface, cropland, grassland, and bare land had a positive correlation on LSWT-day of Tonle Sap Lake. LSA and the area of forest had a negative correlation on LSWT-day. Moreover, through the comparative analysis of 18 years' data, the spatial heterogeneity of LSWT-day was shaped by the distribution pattern of AT, LSA and WLUCC. High LSWT-day occurred in areas with high AT, low LSA and drastic changes in land cover along the lake.

As shown in Fig. 10, the regression models quantitatively described the degree of influence of AT, LSA and WLUCC on LSWT-day for annual time scale. The goodness-of-fit of regression model showed that there were effective fitting models between LSWTday and AT $\left(\mathrm{R}^{2}=0.64\right)$, LSA $\left(\mathrm{R}^{2}=0.58\right)$. In addition, WLUCC also had an impact on LSWT-day. Among them, the effects of cropland, water, forest, impervious surface and grassland on LSWT-day were obvious. 


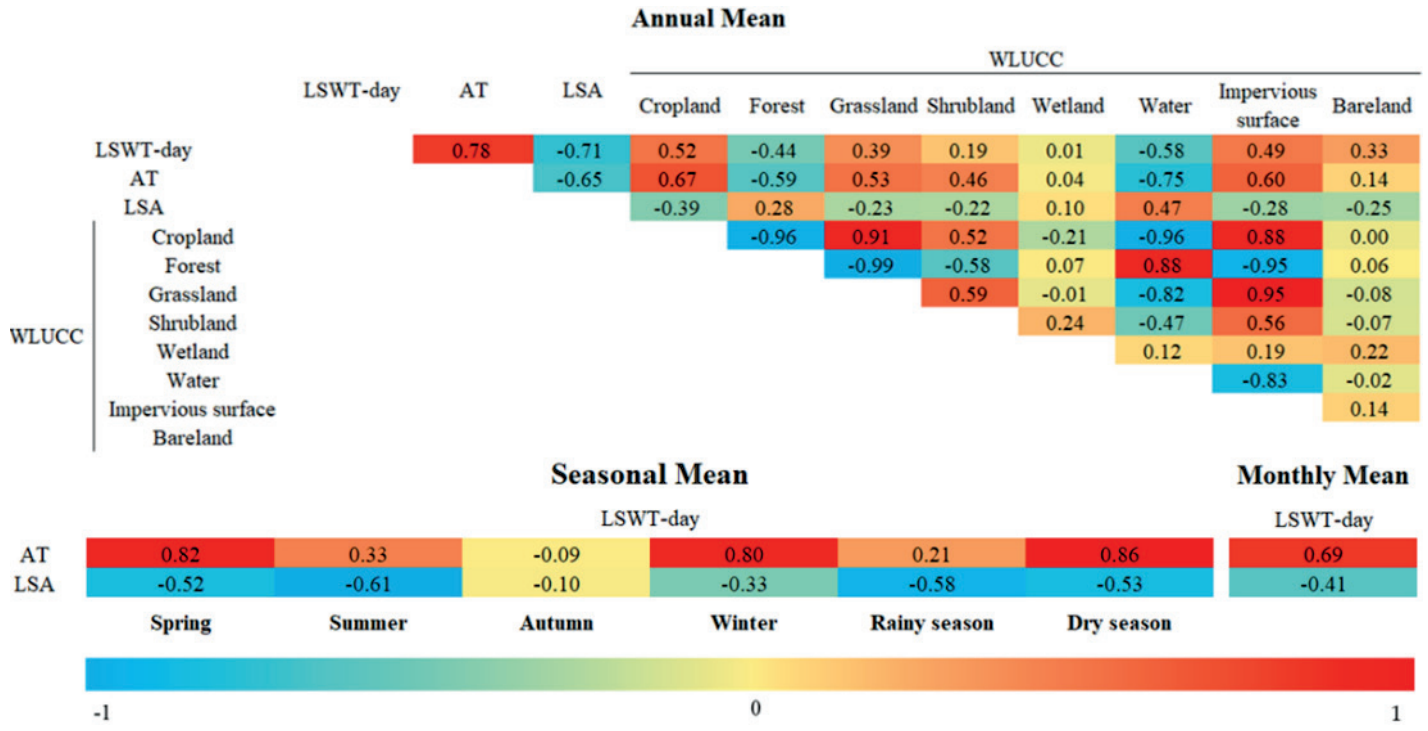

Fig. 9. Pearson correlation coefficients between LSWT-day and AT, LSA, WLUCC for different time scales.

To sum up, under the stress of climate change, AT was still the most important factor affecting LSWT. The strong relationship between LSWT and AT have been acknowledged [40]. Rising AT leads to rising LSWT. Moreover, LSA was another important factor affecting LSWT. The Tonle Sap Lake's unique flood pulse caused dramatic changes in the LSA, which drove changes in LSWT. The relationship between LSA and LSWT was more obvious during the rainy season. This result is consistent with most researches. Woolway et al. [21] indicated that increasing LSA would significantly decrease the diel surface temperature range. Kettle et al. [41] found the LSA and maximum depth were considered important predictors of LSWT. Large, deep lakes tend to be colder than small, shallow ones. Furthermore, due to the interference of human activities, WLUCC had undergone drastic changes. Forest land and water body were decreasing, while cropland, impervious surface,
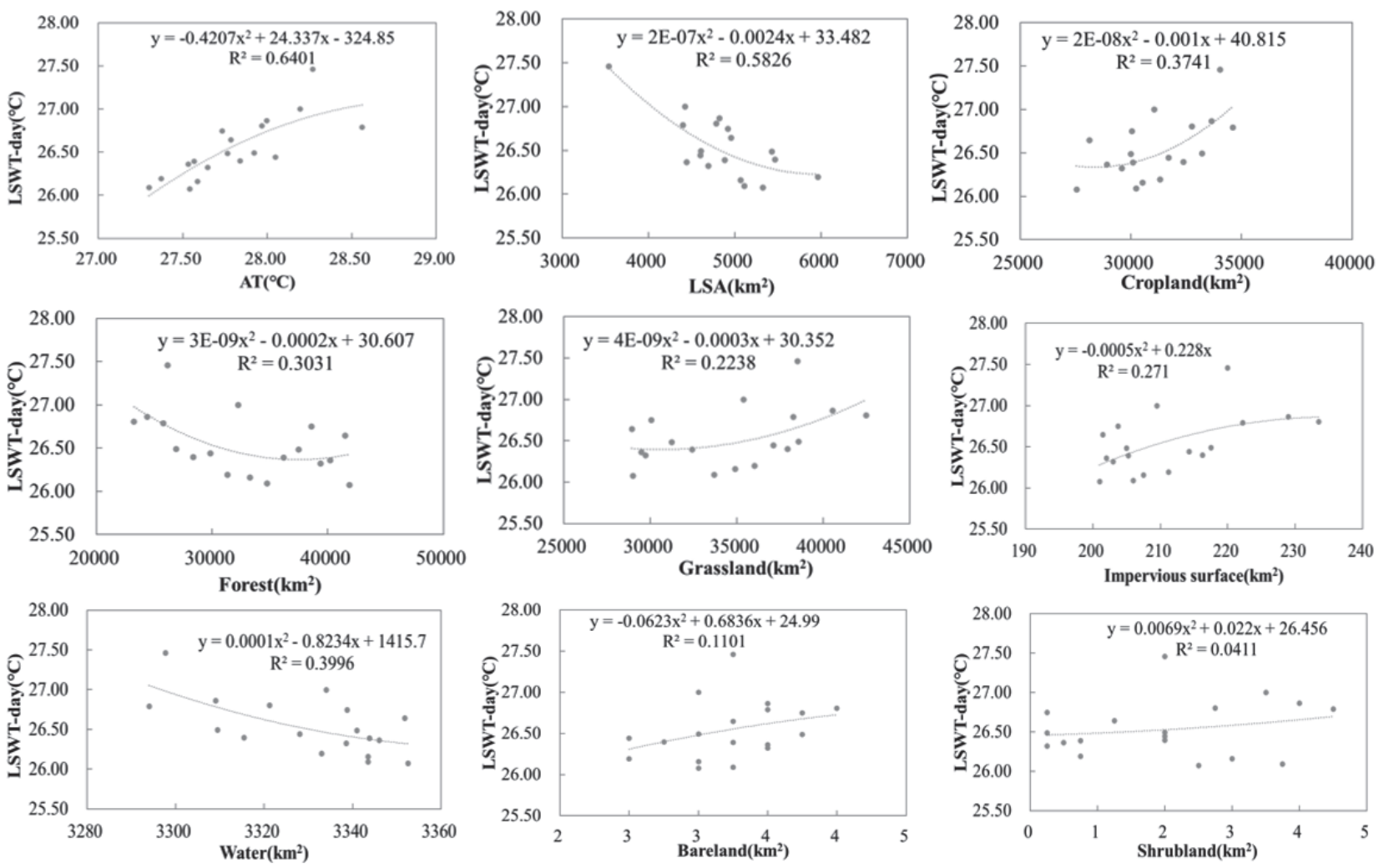

Fig. 10. Relationships between LSWT-day and AT, LSA, WLUCC for annual time scale. 
grassland and bare land were increasing, which would accelerate the rise of LSWT. Yang's studies had shown that large areas of impervious surface are increased, which causes the increase of runoff temperature and further warming of LSWT [22]. This study confirmed that changes in other land use types also affect LSWT.

In addition, as shown in Fig. 9, AT also had obvious correlation on LSA $(\mathrm{r}=-0.65)$ and WLUCC. AT, LSA, WLUCC and LSWT interacted with each other. Regional WLUCC changes the local AT. The increase of AT will accelerate evaporation, decrease precipitation, and reduce LSA. It will further lead to the warming of LSWT. LSWT can respond quickly and directly to long-term climate change. Meanwhile, large lake can regulate the climate of the surrounding areas.

Previous studies show lake temperature is also influenced by geographic, physical habitat and water chemistry [19]. This may be further explained to the weak correlations between Tonle Sap Lake's LSWT-day and AT, LSA in autumn. However, further research is needed to confirm this.

\section{Conclusions}

This research explored a set of technical methods and strategies for Tonle Sap Lake's LSWT variation characteristics and driving factors. Firstly, based on MODIS products (MOD11A2, MOD09A1 and MCD12Q1) and AT images, a long-time series of LSWT, LSA, AT and WLUCC data were obtained by remote sensing technology. Secondly, through GIS geospatial analysis technology, trend analysis and Z-score standardization methods, the temporal-spatial variations of LSWT-day, AT, LSA and WLUCC were analyzed in detail from different time scales. Thirdly, the correlation analysis and regression analysis were used to quantitatively reveal the relationships between LSWT-day and AT, LSA, WLUCC.

The results indicated: 1) the LSWT-day of Tonle Sap Lake showed an obvious upward trend and clear spatial heterogeneity. The average warming rate was $0.3^{\circ} \mathrm{C}$ per decade and its spatial heterogeneity was shaped by the distribution pattern of AT, LSA and WLUCC. 2) Under the global climate warming, AT over the Tonle Sap Lake also showed a warming trend $\left(0.37^{\circ} \mathrm{C}\right.$ per decade). There was a significant positive correlation between AT and LSWT-day at different time scales. AT was a main driving factor affecting LSWT. 3) the LSA of Tonle Sap Lake showed a slightly decreasing tendency $\left(2.5 \mathrm{~km}^{2} /\right.$ year). Tonle Sap Lake's unique flood pulse caused dramatic changes in the LSA. There was an obvious negative correlation between LSA and LSWTday. LSA was an important factor affecting LSWT. 4) due to the interference of human activities, land use types around Tonle Sap Lake had undergone drastic changes. WLUCC was another important driving factor for LSWT warming. The area changes of cropland, water, forest, impervious surface, and grassland in Tonle Sap Lake watershed had obvious effects on LSWT-day.

In summary, LSWT is affected by both climate change and human activity. This paper enhances the understanding of LSWT changing mechanism for similar lakes, and provides decision supports for the environmental protection and management of the lake.

\section{Acknowledgements}

The authors are grateful for the financial support by the National Natural Science Foundation of China [41761084], the China High Technology Research and Development Program 863 [2012AA121402].

\section{Conflict of Interest}

M.P. and K.Y. designed this research; M.P. collected and analyzed the data; M.P. drafted the manuscript; All authors contributed to the modification; All authors have read and approved the final manuscript. The authors declare no conflict of interest.

\section{References}

1. GUDASZ C., BASTVIKEN D., STEGER K., PREMKE K., SOBEK S., TRANVIK L.J. Temperature-controlled organic carbon mineralization in lake sediments. Nature. 466 (7305), 478, 2010.

2. BALSAMO G., DUTRA E., STEPANENKO V.M., VITERBO P., MIRANDA P.M.A., MIRONOV D. Deriving an effective lake depth from satellite lake surface temperature data: A feasibility study with MODIS data. Boreal Environ. Res. 15 (2), 178, 2010.

3. O'REILLY C.M., SHARMA S., GRAY D. K., HAMPTON S.E., READ J.S., ROWLEY R.J., SCHNEIDER P., LENTERS J.D., MCINTYRE P.B., KRAEMER B.M., WEYHENMEYER G.A., STRAILE D., DONG B., ADRIAN R., ALLAN M.G., ANNEVILLE O., ARVOLA L., AUSTIN J., BAILEY J.L., BARON J.S., BROOKES J.D., EYTO E., DOKULIL M.T., HAMILTON D.P., HAVENS K., HETHERINGTON A.L., HIGGINS S.N., HOOK S., IZMEST'EVA L.R., JOEHNK K.D., KANGUR K., KASPRZAK P., KUMAGAI M., KUUSISTO E., LESHKEVICH G., LIVINGSTONE D.M., MACINTYRE S., MAY L., MELACK J.M., MUELLER-NAVARRA D.C., NAUMENKO M., NOGES P., NOGES T., NORTH R.P., PLISNIER P., RIGOSI A., RIMMER A., ROGORA M., RUDSTAM L.G., RUSAK J.A., SALMASO N., SAMAL N.R., SCHINDLER D.E., SCHLADOW S., SCHMID M., SCHMIDT S.R., SILOW E., SOYLU M., TEUBNER K., VERBURG P., VOUTILAINEN A., WATKINSON A., WILLIAMSON C.E., ZHANG G. Rapid and highly variable warming of lake surface waters around the globe. Geophys. Res. Lett. 42 (24), 10773, 2015.

4. TRUMPICKAS J., SHUTER B.J., MINNS C.K. Forecasting impacts of climate change on Great Lakes surface water temperatures. J. Gt. Lakes Res. 35 (3), 454, 2009. 
5. HOU P., LUO Y., YANG K., SHANG C., ZHOU X. Changing characteristics of chlorophyll a in the context of internal and external factors: A case study of Dianchi lake in China. Sustainability. 11 (24), 2019.

6. POLITI E., CUTLER M.E.J., ROWAN J.S. Using the NOAA Advanced Very High Resolution Radiometer to characterise temporal and spatial trends in water temperature of large European lakes. Remote Sens. Environ. 126, 1, 2012.

7. IZMEST'EVA L.R., MOORE M.V., HAMPTON S.E., FERWERDA C.J., GRAY D.K., WOO K.H., PISLEGINA H.V., KRASHCHUK L.S., SHIMARAEVA S.V., SILOW E.A. Lake-wide physical and biological trends associated with warming in Lake Baikal. J. Gt. Lakes Res. 42 (1), 6, 2016.

8. WOOLWAY R.I., WEYHENMEYER G.A., SCHMID M., DOKULIL M.T., DE EYTO E., MABERLY S.C., MAY L., MERCHANT C.J. Substantial increase in minimum lake surface temperatures under climate change. Clim. Change. 155 (1), 81, 2019.

9. SCHAEFFER B.A., IIAMES J., DWYER J., URQUHART, E., SALLS W., ROVER J., SEEGERS B. An initial validation of Landsat 5 and 7 derived surface water temperature for U.S. lakes, reservoirs, and estuaries. Int. J. Remote Sens. 39 (22), 7789, 2018.

10. SCHNEIDER P., HOOK S.J. Space observations of inland water bodies show rapid surface warming since 1985 . Geophys. Res. Lett. 37 (22), 1, 2010.

11. HULLEY G.C., HOOK S.J., SCHNEIDER P. Optimized split-window coefficients for deriving surface temperatures from inland water bodies. Remote Sens. Environ., 115 (12), 3758, 2011.

12. SIMA S., AHMADALIPOUR A., TAJRISHY M. Mapping surface temperature in a hyper-saline lake and investigating the effect of temperature distribution on the lake evaporation. Remote Sens. Environ. 136, 374, 2013.

13. ZHANG G., YAO T., XIE H., QIN J., YE Q., DAI Y., GUO R. Estimating surface temperature changes of lakes in the Tibetan Plateau using MODIS LST data. Journal of Geophysical Research. 119 (14), 8552, 2014.

14. WAN W., LI H., XIE H., HONG Y., LONG D., ZHAO L., HAN Z., CUI Y., LIU B., WANG G., YANG W. A comprehensive data set of lake surface water temperature over the Tibetan Plateau derived from MODIS LST products 2001-2015. Sci. Data. 4 (3), 1, 2017.

15. KE L., SONG C. Remotely sensed surface temperature variation of an inland saline lake over the central qinghaitibet plateau. ISPRS-J. Photogramm. Remote Sens. 98, 157, 2014.

16. YANG K., YU Z., LUO Y. Analysis on driving factors of lake surface water temperature for major lakes in YunnanGuizhou Plateau. Water Res. 184, 2019.

17. LIVINGSTONE D.M., DOKULIL M.T. Eighty years of spatially coherent Austrian lake surface temperatures and their relationship to regional air temperature and the North Atlantic Oscillation. Limnol. Oceanogr. 46 (5), 1220, 2001.

18. XIAO F., LING F., DU Y., FENG Q., YAN Y., CHEN H. Evaluation of spatial-temporal dynamics in surface water temperature of Qinghai Lake from 2001 to 2010 by using MODIS data. J. Arid Land. 5 (4), 452, 2013.

19. SHARMA S., WALKER S.C., JACKSON D.A. Empirical modelling of lake water-temperature relationships: A comparison of approaches. Freshw. Biol. 53 (5), 897, 2008.

20. YANG K., YU Z., LUO Y., YANG Y., ZHAO L., ZHOU $X$. Spatial and temporal variations in the relationship between lake water surface temperatures and water quality
- A case study of Dianchi Lake. Sci. Total Environ. 624 (1), 859, 2018.

21. WOOLWAY R.I., JONES I.D., MABERLY S.C., FRENCH J.R., LIVINGSTONE D.M., MONTEITH D.T., SIMPSON G.L., THACKERAY S.J., ANDERSEN M.R., BATTARBEE R.W., DEGASPERI C.L., EVANS C.D., EYTO E., FEUCHTMAYR H., HAMILTON D.P., KERNAN M., KROKOWSKI J., RIMMER A., ROSE K.C., RUSAK J.A., RYVES D.B., SCOTT D.R., SHILLAND E.M., SMYTH R.L., STAEHR P.A., THOMAS R., WALDRON S., WEYHENMEYER G.A. Diel surface temperature range scales with lake size. PLoS ONE. 11 (3), 2016.

22. YANG K., YU Z., LUO Y., ZHOU X., SHANG C. SpatialTemporal Variation of Lake Surface Water Temperature and Its Driving Factors in Yunnan-Guizhou Plateau. Water Resour. Res. 55 (6), 4688, 2019.

23. KESKINEN M. The lake with floating villages: Socioeconomic analysis of the Tonle Sap Lake. Int. J. Water Resour. Dev. 22 (3), 463, 2006.

24. QU W., HU N., FU J., LU J., LU H., LEI T., PANG Z., LI X., LI L. Analysis of the tonle sap flood pulse based on remote sensing: How much does tonle sap lake affect the mekong river flood? International Archives of the Photogram, 2018.

25. SOK S., YU X., WONG K.K. Impediments to community fisheries management: Some findings in Kompong Pou commune, Krakor District in Cambodia's Tonle Sap. Singap. J. Trop. Geogr. 33 (3), 398, 2012.

26. SEAK S., SCHMIDT-VOGT D., THAPA G.B. Biodiversity monitoring at the tonle sap lake of cambodia: A comparative assessment of local methods. Environ. Manage. 50 (4), 707, 2012.

27. ENOMOTO K., ISHIKAWA S., HORI M., SITHA H., SONG S.L., THUOK N., KUROKURA H. Data mining and stock assessment of fisheries resources in Tonle Sap Lake, Cambodia. Fish. Sci. 77 (5), 713, 2011.

28. UNG P., PENG C., YUK S., TAN R., ANN V., MIYANAGA K., TANJI Y. Dynamics of bacterial community in Tonle Sap Lake, a large tropical flood-pulse system in Southeast Asia. Sci. Total Environ. 664 (2), 414, 2019.

29. IRVINE K.N., RICHEY J.E., HOLTGRIEVE G.W., SARKKULA J., SAMPSON M. Spatial and temporal variability of turbidity, dissolved oxygen, conductivity, temperature, and fluorescence in the lower mekong rivertonle sap system identified using continuous monitoring. International Journal of River Basin Management. 9 (2), 151, 2011v

30. CHEA R., GRENOUILLET G., LEK S. Evidence of water quality degradation in lower mekong basin revealed by self-organizing map. PLoS ONE. 11 (1), 1, 2016.

31. YU W., KIM Y., LEE D., LEE G. Hydrological assessment of basin development scenarios: Impacts on the Tonle Sap Lake in Cambodia. Quat. Int. 503 (3), 115, 2019.

32. SIEV S., PARINGIT E.C., YOSHIMURA C., HUL S. Seasonal changes in the inundation area and water volume of the Tonle Sap River and its floodplain. Hydrology. 3 (4), 2016.

33. KUMMU M., TES S., YIN S., ADAMSON P., JÓZSA J., KOPONEN J., RICHEY J., SARKKULA J. Water balance analysis for the Tonle Sap Lake-floodplain system. Hydrol. Process. 28 (4), 1722, 2014.

34. LAMBERTS D., KOPONEN J. Flood pulse alterations and productivity of the Tonle Sap ecosystem: A model for impact assessment. Ambio. 37 (3), 178, 2008. 
35. SALMIVAARA A., KUMMU M., VARIS O., KESKINEN M. Socio-Economic Changes in Cambodia's Unique Tonle Sap Lake Area: A Spatial Approach. Appl. Spat. Anal. Policy. 9 (3), 413, 2016.

36. KUMMU M., SARKKULA J. Impact of the Mekong River flow alteration on the Tonle Sap flood pulse. Ambio. 37 (3), 185, 2008.

37. XU H. Modification of normalised difference water index (NDWI) to enhance open water features in remotely sensed imagery. Int. J. Remote Sens. 27 (14), 3025, 2006.

38. COCHRANE T.A., ARIAS M.E., PIMAN T. Historical impact of water infrastructure on water levels of the
Mekong River and the Tonle Sap system. Hydrol. Earth Syst. Sci. 18 (11), 4529, 2014.

39. JI X., LI Y., LUO X., HE D. Changes in the lake area of Tonle Sap: Possible linkage to runoff alterations in the Lancang River? Remote Sens. 10 (6), 2018.

40. LUO Y., ZHANG Y., YANG K., YU Z., ZHU Y. Spatiotemporal Variations in Dianchi Lake's Surface Water Temperature From 2001 to 2017 Under the Influence of Climate Warming. IEEE Access. 7 (8), 115378, 2019.

41. KETTLE H., THOMPSON R., ANDERSON N.J., LIVINGSTONE D.M. Empirical modeling of summer lake surface temperatures in southwest Greenland. Limnol. Oceanogr. 49 (1), 271, 2004. 